\title{
Hormone Response to Repeated Electroconvulsive Therapy: Effects of Naloxone
}

\author{
Roger F. Haskett, Athanasios P. Zis, and A. Ariav Albala
}

Plasma prolactin (PRL), cortisol, and growth hormone (GH) were measured before, and at 15-min intervals for $1 \mathrm{hr}$ after, electroconvulsive therapy (ECT). This was repeated over a series of 6 consecutive treatments for each of 12 depressed drug-free inpatients. Patients received naloxone, $2 \mathrm{mg}$ or $20 \mathrm{mg}$, by intravenous infusion before the third and fifth treatment. ECT was consistently followed by a release of PRL and cortisol, although two patterns of $P R L$ response could be distinguished. In eight patients, the PRL response did not change significantly with repeated ECT, whereas in four patients, the plasma $P R L$ increased tenfold after the first treatment and decreased after each successive treatment. The GH level varied widely, with no evidence of a reliable response to ECT. Opiate receptor blockade with low-or high-dose naloxone did not alter the release of PRL or cortisol after ECT. These findings demonstrate a reliable PRL and cortisol response to $E C T$, but do not support a role for endogenous opiates in these hormonal changes.

\section{Introduction}

Plasma levels of prolactin (PRL) increase after the administration of electroconvulsive therapy (ECT) (Ohman et al. 1976; O'Dea et al. 1978; Skrabanek et al. 1981; Arato and Bagdy 1982; Balldin 1982; Whalley et al. 1982). Several observations suggest that this PRL release is the result of the generalized seizure. Unmodified ECT (no anesthesia or muscle relaxant) produced a definite increase in PRL levels (Klimes et al. 1978), whereas simulated ECT (anesthesia without electrical stimulus) produced either a nonsignificant PRL increase (Arato et al. 1980) or a significantly smaller PRL increase than "real" ECT (Deakin et al. 1983). Elevated PRL levels have also been reported after spontaneous generalized seizures in patients suffering from epilepsy (Trimble 1978; Abbott et al. 1980), whereas PRL release was not observed after partial, hysterical, or pseudo seizures (Collins et al. 1983).

Identifying the mechanisms that mediate this hypothalamopituitary response to ECT might increase our understanding of the central neurotransmitter changes associated with

From the Department of Psychiatry, University of Michigan, Ann Arbor, MI.

Supported in part by Public Health Service Grant MH-28294.

Address reprint requests to: Dr. Roger F. Haskett, Department of Psychiatry, University of Michigan, Ann Arbor, MI 48109.

Received September 1, 1984; revised December 10, 1984. 
this treatment. Reports from several studies suggest that endogenous opiates are involved in certain PRL responses. PRL is released after the administration of morphine (Tolis et al. 1975; Extein et al. 1980; $\mathrm{Zis}$ et al, in press) and $\beta$-endorphin (Catlin et al. 1980), and the PRL response to an enkephalin analog is attenuated by prior infusion of the opiate antagonist, naloxone (Stubbs et al. 1978). Naloxone blocks the PRL response to physical exercise (Moretti et al. 1983) and gynecological surgery (Corenblum and Taylor 1981), but does not appear to significantly influence PRL release in the tonic/basal state (Volavka et al. 1980; Cohen et al. 1983) or following hypoglycemia (Grossman et al. 1981), sleep (Martin et al. 1979), and gastroscopy (Morley et al. 1980). Circulating levels of $\beta$ endorphin are reported to increase after ECT (Emrich et al. 1979; Alexopoulos et al. 1983; Misiaszek et al. 1984), although no relationship has been demonstrated between these endogenous opiates and neuroendocrine response to ECT. There has, however, been some speculation that the release of peptides in the hypothalamus-pituitary system may be related to the therapeutic effects of ECT (Fink 1982).

We report the effect of ECT on PRL, cortisol, and growth hormone (GH), with repeated measurements over a series of six consecutive treatments. The present study also examines the hypothesis that the ECT-induced PRL response was a manifestation of endogenous opiate release by observing the effects of pretreatment with the opiate antagonist, naloxone.

\section{Methods}

Twelve patients, nine women and three men, who met the Research Diagnostic Criteria (Spitzer et al. 1978) for either major depressive disorder-endogenous subtype or schizoaffective disorder-depressed type were included in this study. Their mean age was 42.7 years (range 30-71) and the mean pretreatment score on the 17-item Hamilton Depression Rating Scale (HDRS) (Hamilton 1960) was 24.3 (range 13-36). All patients were free of psychotropic medication for at least 5 days prior to ECT and for the duration of the study. Each patient, at a separate interview, had consented to his or her treating psychiatrist's recommendation for ECT before informed consent to this study was obtained.

The first six ECT treatments, administered three times per week, were included in the experimental protocol. The treating psychiatrist determined the total number of treatments for each patient according to clinical response (mean 10.3, range 6-16). All patients had fasted since midnight, and the intravenous catheter used for administration of the anesthetic agents was inserted into the patient's forearm approximately $1 \mathrm{hr}$ before treatment and was kept patent with heparinized saline. Patients were taken to the treatment room approximately $30 \mathrm{~min}$ before ECT and remained there for $1 \mathrm{hr}$ after completion of the treatment. All treatments were given between 8:00 and 9:30 AM.

Standard anesthetic procedure included a premedication with glycopyrrolate (0-0.5 $\mathrm{mg}$ ), which was administered approximately $1 \mathrm{hr}$ before the treatment. Anesthesia was induced with methohexital sodium $(40-100 \mathrm{mg})$, muscle relaxation was obtained with succinylcholine chloride ( $50-80 \mathrm{mg}$ ), and oxygenation was provided by assisted ventilation throughout the procedure. ECT was administered using a Medcraft machine with bitemporal electrode placement. Electrical stimulus ranged from 120 to $160 \mathrm{~V}$ for $0.4-1.0$ sec. Seizure duration was monitored in one limb that was not exposed to the muscle relaxant due to the prior inflation of a sphygmomanometer to suprasystolic pressures.

Blood samples were obtained through a three-way tap in the intravenous line after the 
first 1-2 $\mathrm{ml}$ of blood were discarded. Blood was collected in heparinized tubes, packed in ice, centrifuged within $30 \mathrm{~min}$, and stored at $-20^{\circ} \mathrm{C}$. Samples were drawn before anesthesia, after anesthesia but before the electrical stimulus, and $15,30,45$, and 60 min after the generalized seizure. All plasma samples from a single subject were analyzed in the same assay. Before treatments 3 and 5, naloxone was administered through the intravenous line after the first blood sample and immediately preceding the anesthesia. Subjects 1 through 8 received $2 \mathrm{mg}$ naloxone over $1 \mathrm{~min}$, and subjects 9 through 12 received $20 \mathrm{mg}$ naloxone over 5-10 min.

Plasma PRL was measured by an established double-antibody radioimmunoassay technique (Sinha et al. 1973). The antibody and primary standard were kindly donated by the NIH National Pituitary Agency and prepared by Dr. A. F. Parlow of Harbor General Hospital, Torrance, CA. The linear range of the assay was $0.5-200.0 \mathrm{ng} / \mathrm{ml}$. Samples above $200 \mathrm{ng} / \mathrm{ml}$ were serially diluted until they fell within the assay range. Total plasma corticoids ("cortisol") were measured by the transcortin method of Murphy (1967). GH measurement utilized a radioimmunoassay supplied by Serono.

Results

\section{Hormone Release after Successive ECT Treatment}

A definite increase in plasma PRL and cortisol occurred after each ECT treatment (Figures 1 and 2). The peak levels of PRL and cortisol occurred 15 and $30 \mathrm{~min}$, respectively, after the induced seizure. GH responses were extremely variable, and the mean plasma levels did not change significantly after ECT (Figure 3). The mean baseline levels of PRL and cortisol did not vary significantly between treatment days $(F=0.45$, df $=5,55$, $p=0.81$ and $F=0.17$, df $=5,55, p=0.97$, respectively).

The mean PRL response (peak minus baseline, $\triangle P R L$ ) after each of the six treatments decreased from $94.0 \mathrm{ng} / \mathrm{ml}$ after treatment 1 to $53.6 \mu \mathrm{g} / \mathrm{ml}$ after treatment 6 (Table 1). Inspection of the data, however, suggests that this change in $\triangle P R L$ occurred predominantly in four subjects $(1,5,6$, and 7$)$, with an unusually large $\triangle P R L$ after treatment 1 (range $116.6-292.0 \mathrm{ng} / \mathrm{ml}$ ). Figure 4 shows the $\triangle P R L$ after each treatment for two subgroups of patients selected according to whether the $\triangle P R L$ after treatment 1 was greater $(N=4)$ or less $(N=8)$ than the mean $\triangle P R L$ for all patients after that treatment. We performed a two-way analysis of variance with treatment number as a repeated measures factor and $\triangle P R L$ as a grouping factor. The PRL response showed a significant effect for Group $(F=24.22$, df $=1,10, p=0.0006)$ and Treatment Number $(F=14.92$, df $=5,50$, $p=0.0000$ ). Trend analysis of the Treatment Number main effect revealed a significant linear component ( $F=34.56$, $\mathrm{df}=1,10, p=0.0002$ ), which reflected the overall change (decrease) in mean $\triangle P R L$ with successive treatments. The presence of a significant quadratic component $(F=8.32$, df $=1,10, p=0.0163)$ reflected the much larger decreases in mean $\triangle P R L$ between treatments 1,2 , and 3 than between treatment 3,4 , 5 , and 6. The Group by Treatment Number interaction effect was significant $(F=13.38$, df $=5,50 ; p=0.0000$ ), and trend analysis revealed a significant linear component $(F=34.85$, df $=1,10 ; p=0.0002)$. This reflected the different between-treatment change in mean $\triangle P R L$ for the four patients with large initial $\triangle P R L$ values compared with the other eight patients with lower $\triangle P R L$ values. Baseline PRL levels were not significantly different between the two subgroups of patients. The mean cortisol response (peak minus baseline, $\Delta$ cortisol) after each treatment did not change significantly between treatments $(F=1.67$, df $=5,55 ; p=0.18)$. 


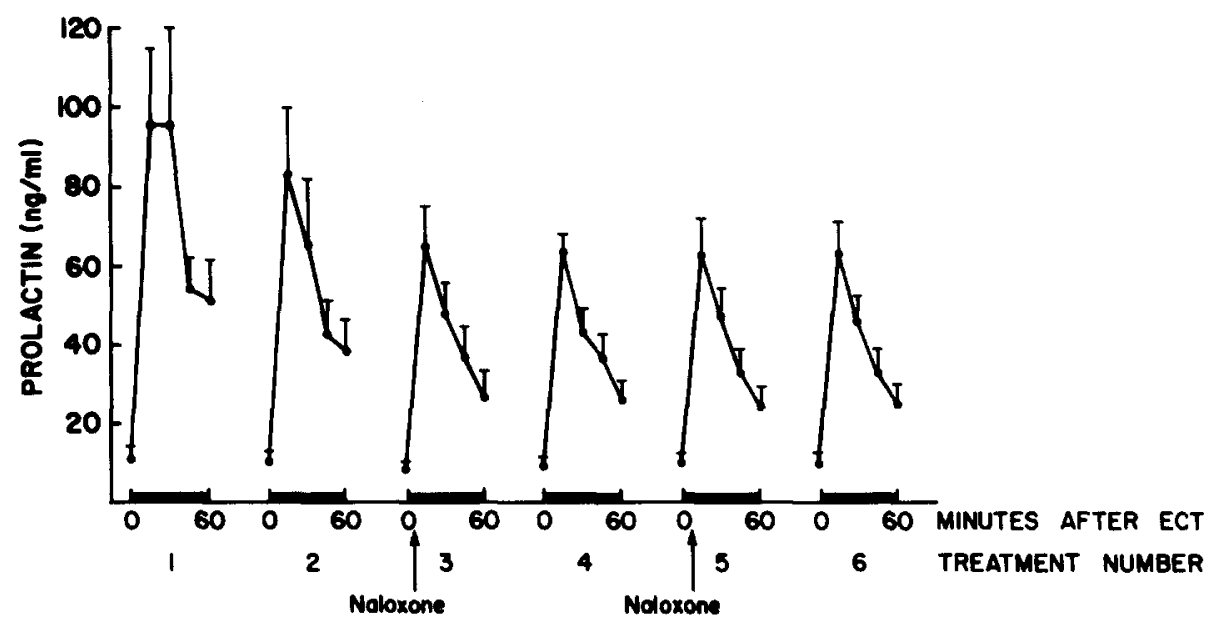

Figure 1. Plasma prolactin concentrations (mean and SEM) before and 15, 30, 45, and $60 \mathrm{~min}$ after first six treatments with ECT $(N=12)$.

\section{Effect of Naloxone Pretreatment}

Figures 5 and 6 show the results of naloxone pretreatment on the PRL and cortisol response after ECT. We performed a three-way analysis of variance with pretreatment drug (naloxone versus control) and order (treatments 3 and 4 versus 5 and 6) as repeated measures factors and naloxone dosage ( $2 \mathrm{mg}$ versus $20 \mathrm{mg}$ ) as a between-groups factor. This analysis excluded treatments 1 and 2 because of the variable change in $\triangle P R L$ described above and compared treatments 3 and 5 (naloxone pretreatment) with treatments 4 and 6 (control). There were no significant effects for naloxone pretreatment, treatment order, or naloxone dosage on either PRL or cortisol response.

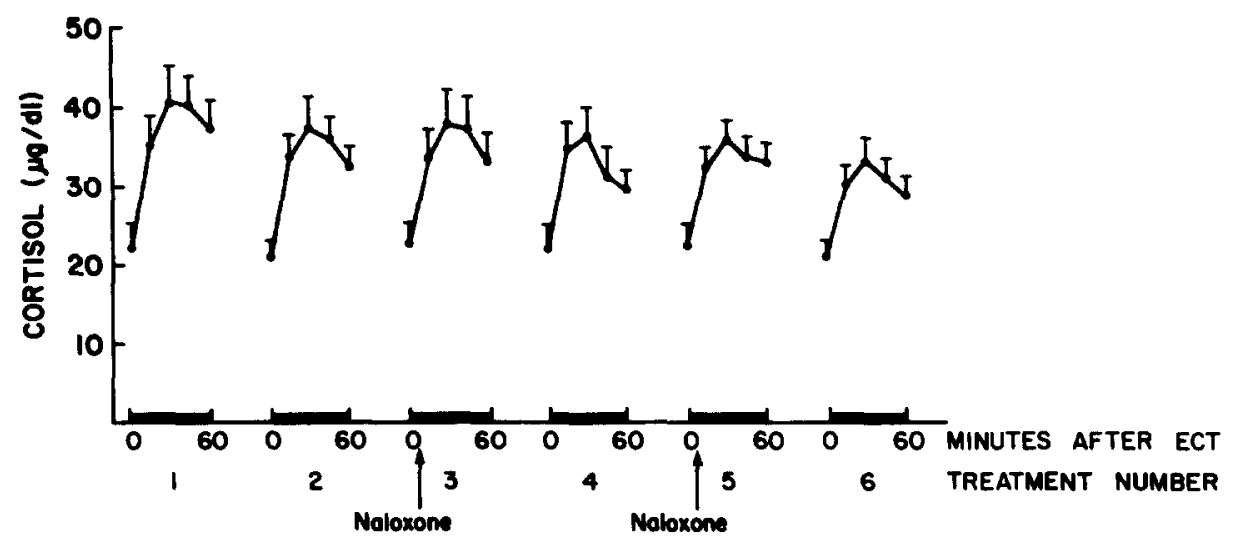

Figure 2. Plasma cortisol concentrations (mean and SEM) before and 15, 30, 45, and $60 \mathrm{~min}$ after first six treatments with ECT $(N=12)$. 


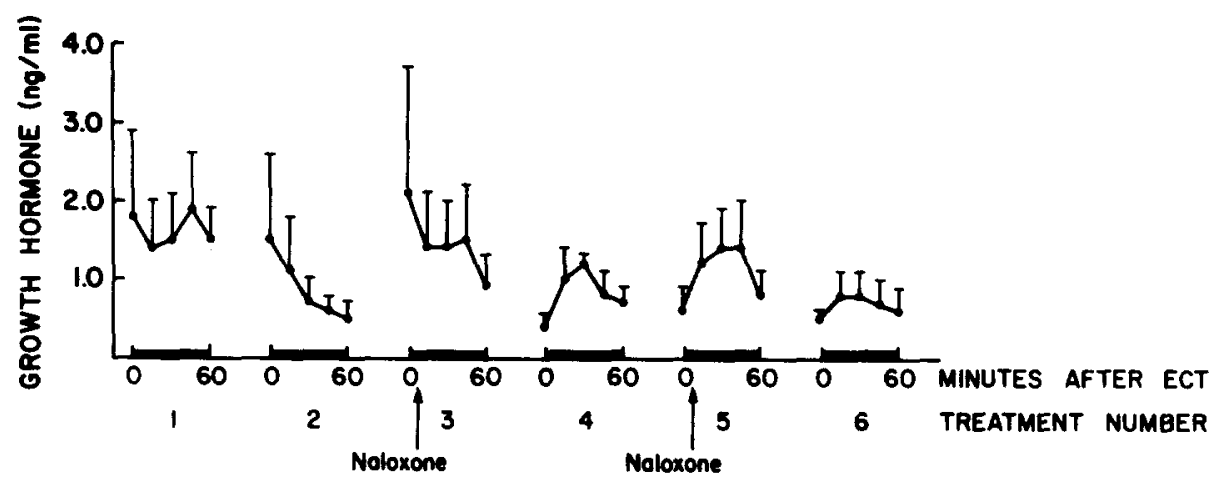

Figure 3. Plasma growth hormone concentrations (mean and SEM) before and $15,30,45$, and 60 min after first six treatments with ECT $(N=12)$.

\section{Relationship between Hormone Release and Treatment Response}

Three patients had an adequate clinical response to 6 treatments with ECT, and their HDRS scores decreased to 1,2 , and 4 . The remaining 9 patients required an additional 1-10 treatments before the course of ECT was completed. When patients were grouped according to whether their $\triangle \mathrm{PRL}$ after treatment 1 was greater $(N=4)$ or less $(N=8)$ than the mean, there was no significant difference between the mean pretreatment HDRS scores (25.3 and 23.9, respectively) or mean numbers of ECT treatments received (8.5 and 9.75 , respectively).

Table 1. Prolactin Response after ECT (Peak Minus Baseline, ng/ml)

\begin{tabular}{|c|c|c|c|c|c|c|c|}
\hline & \multicolumn{6}{|c|}{ Treatment number } & \multirow[b]{2}{*}{ Mean } \\
\hline & 1 & 2 & 3 & 4 & 5 & 6 & \\
\hline \multicolumn{8}{|l|}{ Patient } \\
\hline 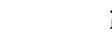 & $292.0^{a}$ & 207.1 & 69.4 & 114.7 & 92.9 & 81.0 & 142.8 \\
\hline 2 & 52.4 & 43.3 & 40.5 & 51.1 & 46.9 & 31.7 & 44.3 \\
\hline 3 & 53.0 & 33.5 & 33.0 & 18.4 & 32.4 & 63.9 & 39.0 \\
\hline 4 & 41.3 & 35.8 & 26.1 & 24.3 & 19.4 & 57.6 & 34.1 \\
\hline$s$ & $116.6^{a}$ & 117.1 & 76.4 & 80.5 & 65.9 & 51.5 & 84.7 \\
\hline c & $191.4^{a}$ & 124.9 & 102.6 & 99.0 & 86.0 & 75.3 & 113.2 \\
\hline 7 & $147.1^{a}$ & 105.1 & 124.2 & 63.5 & 60.3 & 48.5 & 91.4 \\
\hline$\varepsilon$ & 71.6 & 88.0 & 72.5 & 67.7 & 99.8 & 97.1 & 82.8 \\
\hline s & 54.4 & 42.7 & 50.0 & 42.6 & 57.7 & 46.6 & 49.0 \\
\hline 10 & 31.4 & 45.5 & 46.5 & 45.6 & 41.0 & 51.1 & 43.5 \\
\hline 11 & 48.8 & 35.2 & 36.3 & 29.8 & 32.1 & 31.2 & 35.6 \\
\hline 12 & 27.6 & 14.4 & 12.7 & 6.4 & 12.4 & 8.3 & 13.6 \\
\hline Mean & 94.0 & 74.4 & 57.5 & 53.6 & 53.9 & 53.6 & 64.5 \\
\hline
\end{tabular}

aSubjects with $\triangle P R L$ after treatment 1 greater than mean. 


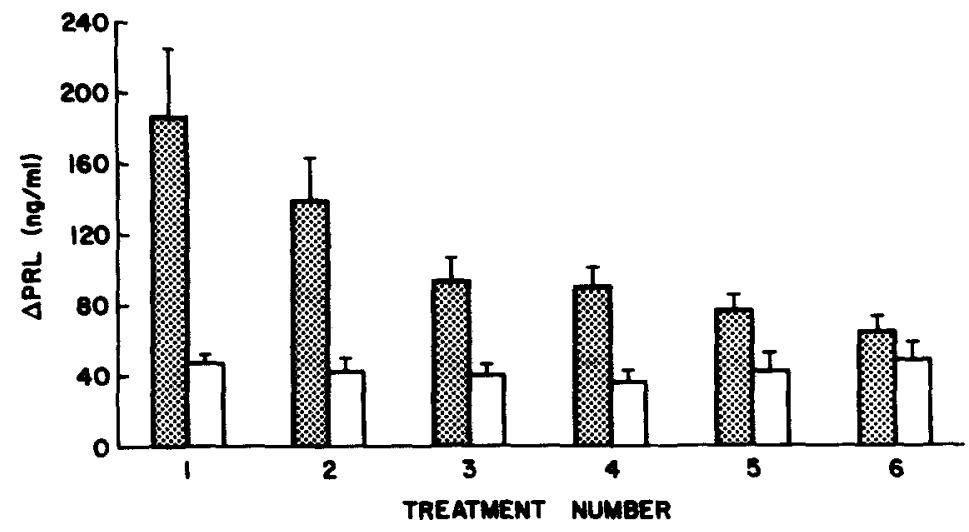

Figure 4. Prolactin response (mean and SEM) after first six treatments with ECT. There were four patients with $\triangle P R L$ after treatment 1 that was greater than the group mean (shaded bars) and eight patients with $\triangle P R L$ after treatment 1 less than the group mean (unshaded bars).

\section{Discussion}

Our data indicate that ECT is consistently followed by a release of PRL, which is in agreement with previous reports. We also examined this phenomenon over repeated treatments. Although the mean $\triangle P R L$ for the total group decreased across the course of treatment, two patterns of response could be distinguished. In eight patients $(67 \%)$, the magnitude of the $\triangle P R L$ was six times the baseline value and did not change significantly with repeated ECT treatment. However, in four patients (33\%), the plasma PRL increased tenfold after the first treatment, and $\triangle \mathrm{PRL}$ decreased after each successive treatment. By the sixth treatment, the $\triangle P R L$ approached the mean value noted after each treatment in the other eight patients. The absence of any significant clinical differences between

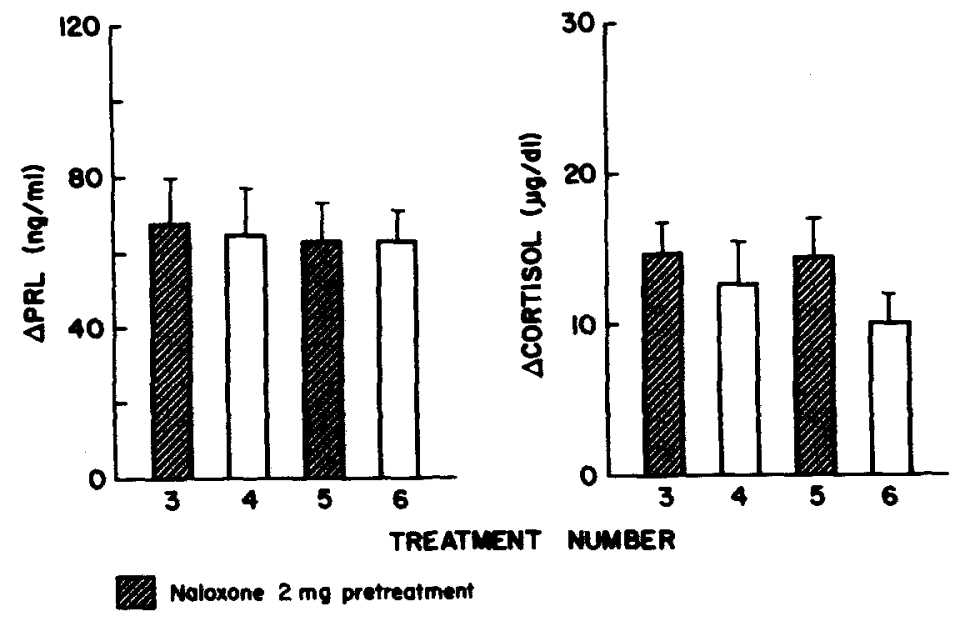

Figure 5. Prolactin and cortisol responses (mean and SEM) after ECT treatments 3-6. Patients received naloxone, $2 \mathrm{mg}$, before ECT treatments 3 and $5(N=8)$. 


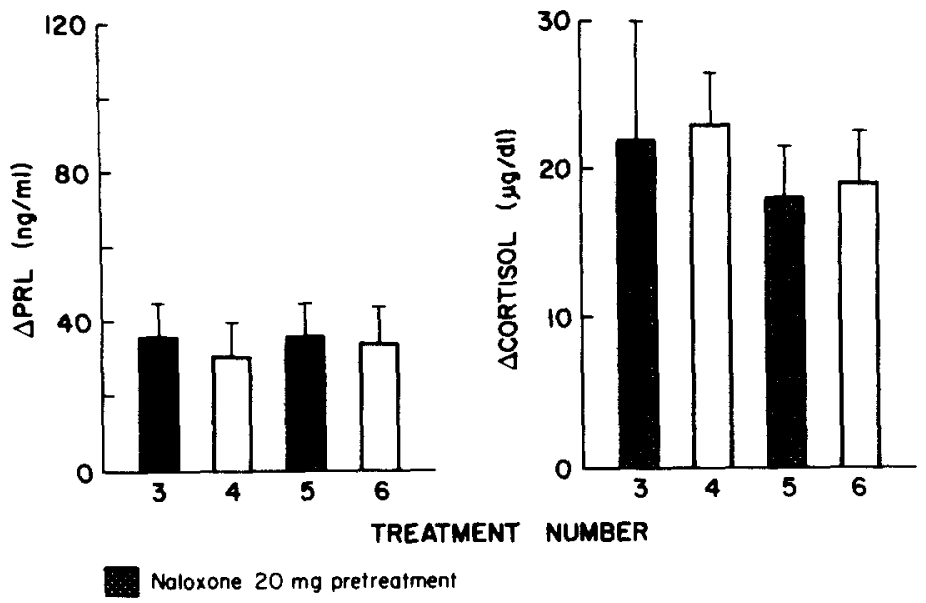

Figure 6. Prolactin and cortisol responses (mean and SEM) after ECT treatments 3-6. Patients received naloxone, $20 \mathrm{mg}$, before ECT treatments 3 and $5(N=4)$.

these two subgroups of patients (mean pretreatment HDRS score and total number of treatments given in the course) suggests that the change in $\triangle P R L$ is not related to the severity of illness or the speed of the clinical response to ECT.

The demonstration of these two disparate patterns of PRL response may provide an explanation for the apparent disagreement between reports that found a decrease in $\triangle P R L$ over a course of treatments (Meco et al. 1978; Deakin et al. 1983) and those that found no significant variation (Skrabanek et al. 1981; Whalley et al. 1982; Linnoila et al. 1984). The etiology of this variability in PRL response between individuals, however, is not readily apparent. PRL secretion can be influenced by a wide variety of factors, for example, circulating estrogens have a stimulatory effect on PRL secretion and increase the responsivity of PRL to various stimuli (Frantz 1978). It is notable that all four patients with large $\triangle P R L$ after ECT were women, mean age 41.3 years, whereas three of eight patients with lower and constant $\triangle P R L$ after ECT were men and the mean age of the remaining five women was $\mathbf{5 4 . 4}$ years. All patients in this study were drug-free, and none had been recently withdrawn from neuroleptics or other drugs known to alter PRL secretion. Further examination of this variability in the pattern of PRL response is needed to determine whether it is an epiphenomenon, e.g., related to sex and estrogen levels, or a marker that distinguishes a valid subcategory of affective disorder.

The release of cortisol after ECT in these patients was also a stable and relatively uniform response that did not change significantly with repeated treatment. This agrees with most studies that have reported changes in cortisol or corticotropin (ACTH) after ECT (Elithorn et al. 1969; Allen et al. 1974; Delitala et al. 1977; Deakin et al. 1983). Whalley et al. (1982) were unable to demonstrate a cortisol response after ECT, but this discrepancy may have resulted from their failure to sample for longer than 6 min after the seizure. Although we did not measure levels of ACTH, it is likely that the observed cortisol response was preceded by an acute release of ACTH (Ylikorkala et al. 1976). As there is evidence that $\beta$-endorphin and ACTH are secreted concomitantly (Guillemin et al. 1977), we believe that our findings are consistent with the previous reports of an ECT-induced release of these pituitary hormones. The GH level in these patients varied 
widely. Most studies have been unable to demonstrate a reliable GH response after ECT (Ryan et al. 1970; Allen et al. 1974; Delitala et al. 1977; Arato et al. 1980; Whalley et al. 1982; Deakin et al. 1983). Vigas et al. (1975) and Skrabanek et al. (1981) did report a GH response, although the patients in the first study received unmodified ECT.

The present data suggest that opiate receptor blockade does not alter the release of PRL and cortisol after ECT. Naloxone is a potent and specific opiate antagonist that rapidly crosses the blood-brain barrier. Maximum concentration of naloxone in the central nervous system (CNS) occurs within minutes of infusion and the plasma half-life is approximately $60 \mathrm{~min}$ (Fishman et al. 1973; Berkowitz et al. 1975). We administered intravenous naloxone infusions in low ( $2 \mathrm{mg}, 0.02-0.05 \mathrm{mg} / \mathrm{kg})$ and high $(20 \mathrm{mg}, 0.20-0.42$ $\mathrm{mg} / \mathrm{kg}$ ) doses because there is evidence for the existence of several opiate receptor subtypes that have differing profiles of response to opiate agonists and antagonists (Lord et al. 1977; Chang and Cuatrecasas 1979). We expected the low dose of naloxone to abolish effects that were mediated by the $\mu$-receptors, as these have a high affinity for naloxone, whereas higher doses are needed to also block the relatively naloxone-insensitive $\delta$ receptors. It remains possible that even higher doses of naloxone could affect the ECTinduced PRL response, although it has been suggested that $16 \mathrm{mg}$ naloxone produces maximal blockade of endogenous opiate tone in the hypothalamic-pituitary-adrenal axis (Grossman et al. 1982). In addition, Cohen et al. (1983) failed to show a naloxone dosedependent effect on PRL secretion with naloxone doses up to $4 \mathrm{mg} / \mathrm{kg}$. Although the administration of naloxone stimulates basal ACTH and cortisol secretion in normals (Volavka et al. 1980; Judd et al. 1981) and naloxone (10 mg) has been reported to enhance the cortisol response to gastroscopy (Morley et al. 1980), we found no difference in the cortisol response to ECT after naloxone.

This study established the reliability and consistency of the PRL and hypothalamic-pituitary-adrenocortical (HPA) axis responses to ECT, especially after treatment 3. PRL secretion and HPA axis function are influenced by multiple neurotransmitter systems, and these aspects of the neuroendocrine response to ECT deserve further study with other pharmacological probes. Recent evidence that exogenous opiates stimulate PRL release but inhibit cortisol secretion (Zis et al. in press) makes it less likely that endogenous opiates are responsible for these ECT-associated hormonal changes. The serotonergic system, however, may be of particular interest, as it has been demonstrated that serotonergic agonists can have a stimulatory effect on both PRL and cortisol release (see reviews by Checkley, 1980, and Reichlin, 1981). Systematic examination of these phenomena may eventually lead to clarification of the neurochemical events accompanying ECT.

The authors thank Patricia Nelson, R.N., James Ritchie, M.S., and Kathleen F. Johnson, B.A., for their invaluable assistance with this study.

\section{References}

Abbott RJ, Browning MCK, Davidson DLW (1980): Serum prolactin and cortisol concentrations after grand mal seizures. $J$ Neurol Neurosurg Psychiatry 43:163-167.

Alexopoulos GS, Inturrisi CE, Lipman R, Frances R, Haycox J, Dougherty JH Jr, Rossier J (1983): Plasma immunoreactive $\beta$-endorphin levels in depression. Effect of electroconvulsive therapy. Arch Gen Psychiatry 40:181-183. 
Allen JP, Denney D, Kendall JW, Blachly PH (1974): Corticotropin release during ECT in man. Am J Psychiatry 131:1225-1228.

Arato M, Bagdy G (1982): Neuroendocrine study of the mechanism of action of electroconvulsive therapy. Neuropsychobiology 8:162-168.

Arato M, Erdos A, Kurcz M, Vermes I, Fekete M (1980): Studies on the prolactin response induced by electroconvulsive therapy in schizophrenics. Acta Psychiatr Scand 61:239-244.

Balldin J (1982): Factors influencing prolactin release induced by electroconvulsive therapy. Acta Psychiatr Scand 65:365-369.

Berkowitz BA, Ngai SH, Hempstead J, Spector S (1975): Disposition of naloxone: Use of a new radioimmunoassay. J Pharmacol Exp Ther 195:499-504.

Catlin DH, Poland RE, Gorelick DA, Gerner RH, Hui KK, Rubin RT, Li CH (1980): Intravenous infusion of $\beta$-endorphin increases serum prolactin, but not growth hormone or cortisol, in depressed subjects and withdrawing methadone addicts. J Clin Endocrinol Metab 50:1021-1025.

Chang K, Cuatrecasas P (1979): Multiple opiate receptors. J Biol Chem 254:2610-2618.

Checkley SA (1980): Neuroendocrine tests of monoamine function in man: A review of basic theory and its application to the study of depressive illnesss. Psychol Med 10:35-53.

Cohen MR, Cohen RM, Pickar D, Weingartner H, Murphy DL (1983): High dose naloxone infusions in normals. Arch Gen Psychiatry 40:613-619.

Collins WCJ, Lanigan O, Callaghan N (1983): Plasma prolactin concentrations following epileptic and pseudoseizures. J Neurol Neurosurg Psychiatry 46:505-508.

Corenblum B, Taylor PJ (1981): Mechanisms of control of prolactin release in response to apprehension stress and anesthesia-surgery stress. Fertil Steril 36:712-715.

Deakin JFW, Ferrier IN, Crow TJ, Johnstone E, Lawler P (1983): Effects of ECT on pituitary hormone release: Relationship to seizure, clinical variables and outcome. $B r J$ Psychiatry 143:618-624.

Delitala A, Masala A, Rosati G, Aiello I, Agnetti V (1977): Effect of electroconvulsive therapy (electroshock) on plasma ACTH, GH, LH, FSH, TSH and 11-OH-CS in patients with mental disorders. Neurology (Panminerva Medica) 19:237-243.

Elithorn A, Bridges PK, Hodges JR, Jones MT (1969): Adrenocortical responsiveness during courses of electroconvulsive therapy. Br J Psychiatry 115:575-580.

Emrich HM, Hollt V, Kissling W, Fischler M, Laspe H, Heinemann HV, Zerssen D, Herz A (1979): $\beta$-endorphin-like immunoreactivity in cerebrospinal fluid and plasma of patients with schizophrenia and other neuropsychiatric disorders. Pharmakopsychiatry 12:269-276.

Extein I, Pottash ALC, Gold MS, Sweeney DR, Martin DM, Goodwin FK (1980): Deficient prolactin response to morphine in depressed patients. Am J Psychiatry 137:845-846.

Fink M (1982): Neuroendocrine aspects of convulsive therapy. In Abrams R, Essman WB (eds), Electroconvulsive Therapy: Biological Foundations and Clinical Applications. New York: Spectrum, pp 187-198.

Fishman J, Roffwarg H, Hellman L (1973): Disposition of naloxone 7, 8-3H in normal and narcoticdependent men. J Pharmacol Exp Ther 187:575-580.

Frantz AG (1978): Prolactin. N Eng J Med 298:201-207.

Grossman A, Stubbs WA, Gaillard RC, Delitala G, Rees LH, Besser GM (1981): Studies of the opiate control of prolactin, GH, and TSH. Clin Endocrinol 14:381-386.

Grossman A, Gaillard RC, McCartney P, Rees LH, Besser GM (1982): Opiate modulation of the pituitary-adrenal axis: Effects of stress and circadian thythm. Clin Endocrinol 17:279-286.

Guillemin R, Vargo T, Roosier J, Minick J, Ling N, Rivier C, Vale W, Bloom F (1977): $\beta$ endorphin and adrenocorticotropin are secreted concomitantly by the pituitary gland. Science 197:1367-1369.

Hamilton MA (1960): A rating scale for depression. J Neurol Neurosurg Psychiatry 23:56-62.

Judd LL, Janowsky DS, Zettner A, Huey LY, Takahashi KI (1981): Effects of naloxone-HCl on cortisol levels in patients with affective disorder and normal controls. Psychiatry Res 4:277-283. 
Klimes I, Vigas M, Jurcovicova J, Wiederman V (1978): Serum prolactin after electroconvulsive therapy in man. Endokrinologie 72:371-373.

Linnoila M, Litovitz G, Scheinin M, Chang M, Cutler NR (1984): Effects of electroconvulsive treatment on monoamine metabolites, growth hormone and prolactin in plasma. Biol Psychiatry 19:79-84.

Lord JAH, Waterfield AA, Hughes J, Kosterlitz HW (1977): Endogenous opioid peptides: Multiple agonists and receptors. Nature 267:495-499.

Martin JB, Tolis G, Woods I, Guyda H (1979): Failure of naloxone to influence physiological growth hormone and prolactin secretion. Brain Res 168:210-215.

Meco G, Casacchia M, Carchedi F, Falaschi P, Rocco A, Frajese G (1978): Prolactin response to repeated electroconvulsive therapy in acute schizophrenia. Lancet 2:999.

Misiaszek J, Cork RC, Hameroff SR, Finley J, Weiss JL (1984): The effect of electroconvulsive therapy on plasma $\beta$-endorphin. Biol Psychiatry 19:451-455.

Moretti C, Fabbri A, Gnessi L, Cappa M, Calzolari A, Fraioli F, Grossman A, Besser GM (1983): Naloxone inhibits exercise-induced release of PRL and GH in athletes. Clin Endocrinol 18:135-138.

Morley JE, Baranetsky NG, Wingert TD, Carlson HE, Herschman JM, Melmed S, Levin SL, Jamison KR, Weitzman R, Chang RJ, Varner AA (1980): Endocrine effects of naloxone-induced opiate receptor blockage. J Clin Endocrinol Metab 50:251-257.

Murphy BEP (1967): Some studies of the protein-binding of steroids and their application to the routine micro and ultramicro measurement of various steroids in body fluids by competitive protein-binding radioassay. J Clin Endocrinol Metab 23:973-990.

O'Dea JPK, Gould D, Hallberg M, Wieland RG (1978): Prolactin changes during electroconvulsive therapy. Am J Psychiatry 135:609-611.

Ohman R, Balldin J, Walinder J, Wallin L, Abrahamsson L (1976): Prolactin response to electroconvulsive therapy. Lancet 2:936-937.

Reichlin S (1981): Neuroendocrinology. In Williams RH (ed), Textbook of Endocrinology. Philadelphia: W. B. Saunders, pp 615-618.

Ryan RJ, Swanson DW, Fairman C, Mayberry WE, Spandoni AJ (1970): Effects of convulsive electroshock on serum concentrations of follicle-stimulating hormone, luteinizing hormone, thyroid-stimulating hormone and growth hormone in man. J Clin Endocrinol 30:51-58.

Sinha YN, Selby FB, Lewis UJ, Vander Laan WP (1973): A homologous radioimmunoassay for human prolactin. J Clin Endocrinol Metab 36:509-516.

Skrabanek P, Balfe A, Webb M, Maguire J, Powell D (1981): Electroconvulsive therapy (ECT) increases plasma growth hormone, prolactin, luteinizing hormone and follicle-stimulating hormone but not thyrotropin or substance P. Psychoneuroendocrinology 6:261-267.

Spitzer RL, Endicott J, Robins E (1978): Research Diagnostic Criteria (RDC) for a Selected Group of Functional Disorders, ed 3. New York: New York State Psychiatric Institute.

Stubbs WA, Jones A, Edwards CRW, Delitala G, Jeffcoate WJ, Ratter SJ, Besser GM, Bloom SR, Alberti KGMM (1978): Hormonal and metabolic responses to an enkephalin analogue in normal man. Lancet 2:1225-1227.

Tolis G, Hickey J, Guyda H (1975): Effect of morphine on serum growth hormone, cortisol, prolactin and thyroid stimulating hormone in man. J Clin Endocrinol Metab 41:797-800.

Trimble MR (1978): Serum prolactin in epilepsy and hysteria. Br Med J 2:1682.

Vigas M, Stowasserova N, Nemeth S, Jurcovicova J (1975): Effect of electroconvulsive therapy without anticonvulsive premedication on serum growth hormone in man. Hormone Res 6:65-70.

Volavka J, Bauman J, Pevnick J, Reker D, James B, Cho D (1980): Short-term hormonal effects of naloxone in man. Psychoneuroendocrinology 5:225-234.

Whalley LJ, Dick H, Watts AG, Christie JE, Rosie R, Levy G, Sheward WJ, Fink G (1982): Immediate increases in plasma prolactin and neurophysin but not other hormones after electroconvulsive therapy. Lancet 2:1064-1068.

Ylikorkala O, Kauppila A, Haapalahti J, Karppanen H (1976): The effect of electric convulsion 
therapy on the circulating concentrations of pituitary hormones, cortisol and cyclic adenosine monophosphate. Clin Endocrinol 5:571-574.

Zis AP, Haskett RF, Albala AA, Carroll BJ: Morphine inhibits cortisol and stimulates prolactin secretion in man. Psychoneuroendocrinology, in press. 